Assiut University web-site: www.aun.edu.eg

\title{
OCCURRENCE OF HELICOBACTER SPECIES WITH SPECIAL PRIORITY TO H. PYLORI IN HEN'S EGGS
}

\author{
MARWA EZZAT ABDEL GAID KHOLEAF ${ }^{1}$, MOSTAFA KHALIL MOSTAFA ${ }^{2}$, \\ NAGAH MOHAMMED SAAD ${ }^{2}$ and MARWA MOHAMMED NABIL HASSAN ${ }^{1}$ \\ ${ }^{1}$ Department of Food Hygiene, Animal Health Research Institute, Assiut Lab. \\ ${ }^{2}$ Department of Food Hygiene, Faculty of Vet. Med., Assiut University, Egypt
}

Received: 24 June 2018; Accepted: 9 July 2018

\begin{abstract}
A total of 300 random eggs, representing 60 samples, (30 from baladi hens, and 30 from poultry farms) were collected from different markets, poultry farms, groceries and supermarkets located in Assuit governorate, Egypt. Each egg sample composed of 5 eggs and these samples were examined for the incidence of Helicobacter species using Helicobacter pylori special peptone agar (HPSPA). The results revealed that the incidence of Helicobacter species from examined baladi hen's egg shells was 10 (33.33\%), poultry farms hen's egg shells was $9(30 \%)$ and $1(3.33 \%)$ from examined baladi hen's egg content samples. H. pylori was isolated in a percentage of $5(16.67 \%)$ from examined baladi hen's egg shells while from poultry farms hen's egg shells was 4 (13.33\%). In addition, other Helicobacter species were isolated from the examined samples as $H$. cinaedi in a percentage of $(6.67 \%)$ from examined baladi hen's egg shells and (10\%) from examined poultry farms hen's egg shells. H. felis was isolated in a percentage of (6.67\%) from both examined baladi and poultry farms hen's egg shells samples and $H$. pullorum was isolated in a percentage of (3.33\%) from examined baladi hen's egg shells. Also, it was isolated from examined baladi hen's egg contents in a percentage of (3.33\%). Identification of ureC gene for $H$. pylori isolated from both baladi hen's egg shells and poultry farms hen's egg shells by using polymerase chain reaction (PCR) revealed that 8 from 9 samples were positive for $H$. pylori by using (PCR) in a percentage of $(88.89 \%)$.
\end{abstract}

Key words: Helicobacter, H. Pylori, Hen's Eggs.

\section{INTRODUCTION}

Eggs are among the few foods that are used throughout the world regardless of religion and ethnic groups (Stadelman and Cotterill, 2001). The hen's egg is one of the perfectly preserved biological items found in nature and its nutritional benefits are well recognized. Eggs remain a stable food within the human diet, consumed by people throughout the world in various dishes and considered very nutritious and a cheap source of protein (Osei-Somuah et al., 2003).

Eggs also have many functional properties such as foaming, emulsifying and unique color and flavor, which are important in several food products (Stadelman and Cotterill, 2001). Freshly laid eggs are generally devoid of organisms, however, following exposure to environmental conditions, may become

Corresponding author: Dr. Marwa Mohammed Nabil Hassan E-mail address: ahmednofel122@yahoo.com

Present address: Department of Food Hygiene, Animal Health Research Institute, Assiut Lab. contaminated with different types of microorganisms (Ellen et al., 2000). Eggs are liable to contamination either before laying (congenitally) or after laying (extragenitally), when the microorganisms reach the egg contents through penetration pores of shell cause low egg quality, low shelf life, low safety and induce public health hazards (Board and Fuller, 1994). In addition, fecal matter, improper washing, using of contaminated water and bad handling are the common sources of contamination. In spite of their high nutritive value, eggs were responsible for several outbreaks and were a vehicle for transmission of certain human pathogens as Helicobacters (Miyamota et al., 1998; Hangombe et al., 1999; Gast et al., 2004).

Helicobacter is a genus of Gram-negative bacteria possessing a characteristic helical shape. They were initially considered to be members of the Campylobacter genus, but in 1989 Goodwin et al. published sufficient reasons to justify his new genus name of Helicobacter. The Helicobacter genus contains about 35 species and some species are pathogenic and known to colonize the gastrointestinal and biliary tracts of many animal species. They are 
grouped into two groups gastric and enterohepatic Helicobacter species (Boyanova, 2011).

Gastric Helicobacter species including H. pylori, $H$. acinonychis, $H$. bizzozeronii, $H$. felis, $H$. mustelae, $H$. nemestrinae, $H$. salomonis and $H$. suncus. Enterohepatic Helicobacter species as $H$. pullorum, $H$. bilis, $H$. canadensis, $H$. canis, $H$. cholecystus, $H$. cinaedi, $H$. fennelliae, $H$. ganmani, $H$. hepaticus, $H$. mesocricetorum, $H$. muridarum, $H$. pametensis, $H$. rodentium, $H$. trogontum and $H$. typhlonicus (Solnick and Vandamme, 2001).

There are many Helicobacter species that infect human and leading to many medical condition, as $H$. helimannii which leads to duodenal ulcer, gastric carcinoma and mucosa associated lymphoid tissue (MALT) tumors. Also H. felis which is usually associated with gastric disease and many species isolated from human diarrheal samples included $H$. cinaedi, $H$. canis, $H$. pullorum, $H$. fennellae, $H$. canadensis and $H$. pylori. Additially, there are Helicobacter species have been isolated from livers and have been associated with hepatic diseases as $H$. hepaticus which lead to hepatitis and hepatic carcinoma (On et al., 2002).

The best known and the most important in terms of global impact on human disease is $H$. pylori in which the definitive reservoir is assumed to be humans (Drumm et al., 1990). The history of discovering and isolation of $H$. pylori was first documented since a century ago. $H$. pylori was first discovered in the stomachs of patients with gastritis and ulcers in 1982 by (Marshall and Warren 1983) and they awarded the 2005 Nobel Prize in Physiology or Medicine. Acute infection with $H$. pylori may appear as an acute gastritis with abdominal pain or nausea (Butcher, 2003) which develop to chronic gastritis. The symptoms are often stomach pains, nausea, bloating, belching, and sometimes vomiting or black stool (Ryan, 2010).

About $10-20 \%$ of those infected with $H$. pylori develop gastric and duodenal ulcers. $H$. pylori infection is also associated with $1-2 \%$ lifetime risk of stomach cancer and less than $1 \%$ risk of gastric mucosa associated lymphoid tissue lymphoma (MALT) (Kusters et al., 2006). H. pylori has been recognized as the principal cause of gastric disease which is more severe than that caused by $H$. helimannii and cause gastritis, peptic ulcer, gastric carcinomas, and mucosa- associated lymphoid tissue lymphoma (Komoto et al., 1998). H. pylori was classified as a definitive carcinogen to human which may play a causative role in development of up to $90 \%$ of gastric cancers (Forman et al., 1994).

There was association between $H$. pylori infection and hypertension and myocardial infarction. (Whincup et al., 1996). H. pylori infection presents approximately in half of the world's population (Lambert et al., 1995). The organism can be found in 70-90\% and 25$50 \%$ of the population in developing and developed countries, respectively (Sykora et al., 2006; Vale and Vitor, 2010) depending on environmental and socioeconomic factors. In spite of the general idea about the low prevalence of gastric cancer, H. pylori infection considered the fourth most common type of cancer and the second leading cause of cancer- related deaths worldwide (WHO, 2010). The minimum infectious dose of $H$. pylori during primary and secondary infection was $10^{4}$ bacteria (Solnick et al., 2001).

Moreover, Enterohepatic Helicobacter species, including $H$. pullorum, is increasingly recognized as microbial pathogen in humans and animals (On et al., 1996; On et al., 2002). Helicobacter pullorum was first described by Stanley et al. (1994). On et al. (1996) indicated that $H$. pullorum was originally isolated from the feces, the intestines and damaged livers of broilers and laying hens (Burnens et al., 1994; Stanley et al., 1994), and also from the feces of humans (Ceelen et al., 2005). H. pullorum has been related to enteritis and hepatitis in broiler chickens and laying hens, diarrhea, gastroenteritis, and liver disease in humans (Burnens et al., 1994; Stanley et al., 1994; Young et al., 2000 and Ceelen et al., 2005). The organism can be considered a food borne human pathogen (Ceelen et al., 2006).

Fox et al. (1998) observed that H. pullorum, H. bilis and $H$. rappini were found to cause some kinds of extra digestive diseases in liver and gall bladder of human with chronic cholecystitis.

Since the isolation of Helicobacter species from eggs is very scarce and to determine whether eggs act as a vehicle in transmission of Helicobacter species, therefore this work was planned to study the incidence of Helicobacter species in hen's eggs, in addition to identification and confirmation of $H$. pylori ure $\mathrm{C}$ gene by using PCR.

\section{MATERIALS and METHODS}

\section{Isolation and identification of Helicobacter species from hen's eggs. Collection of samples:}

A total of 300 random eggs, representing 60 samples, (30 from baladi hens', and 30 from poultry farms) were collected from, poultry farms, groceries and supermarkets located in Assiut Governorate, Egypt. Each egg sample (composed of 5 eggs) was placed in a sterile plastic bag and dispatched to the laboratory with a minimum of delay where they were prepared and examined. 
Preparation of samples:

Egg shells: Egg shells were tested by a surface rinse method as described by Moats (1980).

Egg contents: The egg sample was prepared for evacuation of its content according to Speck (1976).

Isolation of Helicobacter species: The technique adopted by Stevenson et al. (2000) was used.

Enrichment: One milliliter of rinsed solution and egg content samples were aseptically inoculated into a sterile test tubes containing $10 \mathrm{ml}$ of selective enrichment broth Helicobacter pylori special peptone broth (HPSPB) containing selective supplement which is Vancomycin5.0 $\mathrm{mg}$, Trimethoprim lactate $2.5 \mathrm{mg}$, Cefsulodin $2.5 \mathrm{mg}$ and Amphotericin B $2.5 \mathrm{mg}$. The inoculated tubes were incubated at $37^{\circ} \mathrm{C}$ for 48 hours in an atmosphere of $6 \% \mathrm{O}_{2}, 10 \% \mathrm{CO}_{2}$ and $84 \% \mathrm{~N}_{2}$ by $\mathrm{CO}_{2}$ incubator (HERA cell 150 Thermo scientific).

Selective plating: Loopfulls from incubated broth cultures were then streaked on HPSPA supplemented with Helicobacter selective supplement (Oxoid Code SR147E). All the cultured plates were inspected after 3, 5 days. Suspected colonies grow, slowly, small not exceeding $2 \mathrm{~mm}$ in diameter, translucent, circular and convex.

Identification of Helicobacter (Solnic and Vandamme, 2001): Gram stain and Biochemical characteristics which include Oxidase production test, Catalase production test, Urease production test, Hippurate hydrolysis test, Nitrate reduction test, Glycine tolerance test and Salt tolerance test (Solnic and Vandamme, 2001).

Identification of ureC gene for $H$. pylori by using PCR

DNA Extraction using QIA amp kit (Shah et al., 2009):

After overnight culture on nutrient agar plates, one or two colonies were suspended in $20 \mathrm{ml}$ of sterile distilled water, and the suspension was then heated at $100^{\circ} \mathrm{C}$ for 20 minutes. Accurately, 50-200 $\mu 1$ of the culture were placed in Eppendorf tube and Equal volume from the lysate $(50-200 \mu \mathrm{l})$ was added, after addition of $20-50 \mu 1$ of proteinase $\mathrm{K}$, the mixture was incubated at $56{ }^{\circ} \mathrm{C}$ for $20-30$ min. After incubation, $200 \mu \mathrm{l}$ of $100 \%$ ethanol was added to the lysate. The solution was added to the column and centrifuged at $8000 \mathrm{rpm}$ for $1 \mathrm{~min}$, then the filtrate was discarded. The sediment was washed using AW1 buffer $(200 \mu \mathrm{l})$, the column was centrifuged at $8000 \mathrm{rpm} / 1 \mathrm{~min}$, and the filtrate was discarded. Washing was applied by using the AW2 buffer $(200 \mu 1)$, the column was centrifuged at $8000 \mathrm{rpm} / 1 \mathrm{~min}$, and the filtrate was discarded. The column was placed in a new clean tube then, 25-50 $\mu \mathrm{l}$ from the Elution buffer was added, centrifuged at $8000 \mathrm{rpm} / 1 \mathrm{~min}$, and then the column was discarded. The filtrate was put in clean tube containing the pure genomic DNA and nucleic acid was eluted with $100 \mu \mathrm{l}$ of elution buffer provided in the kit.

\section{Amplification reactions of DNA: Amplification of ureC gene for $\boldsymbol{H}$. pylori (Kianpour et al., 2014):}

The amplification was performed on a Thermal Cycler (Master cycler, Eppendorf, Hamburg, Germany) using $50 \mu \mathrm{L}$ containing $5 \mu \mathrm{L} 10 \times$ buffer $+\mathrm{MgCl} 2,2 \mathrm{mM}$ dNTP, 2 unit Taq DNA polymerase, $100 \mathrm{ng}$ genomic DNA as a template, and 25 picomole of each primer. PCR was performed using a thermal cycler (Eppendorf Co., Germany) under the following conditions: an initial denaturation for 10 minutes at $94^{\circ} \mathrm{C}$; 35 cycles for 1 minute at $94^{\circ} \mathrm{C}, 1$ minute at $55^{\circ} \mathrm{C}, 1$ minute at $72^{\circ} \mathrm{C}$, and a final extension at $72^{\circ} \mathrm{C}$ for 10 minutes.

PCR amplified products were analyzed by $1.5 \%$ of agarose gel electrophoresis in 1x TBE buffer stained with ethidium bromide and visualized on UV transilluminator. A 100 bp plus DNA Ladder was used to determine the fragment sizes and the gene product was 294 bp.

\section{Primer sequences used for PCR identification system:}

Application of PCR for detection of urease C gene (ureC) aka phosphoglucosamine mutase gene (glmM) specific for identification and characterization of $H$. pylori was performed essentially by using Primers (Pharmacia Biotech) as shown in the following table:

\begin{tabular}{|c|c|c|c|}
\hline Target gene & Oligonucleotide sequence $\left(5^{\prime} \rightarrow 3^{\prime}\right)$ & $\begin{array}{l}\text { Product size } \\
\text { (bp) }\end{array}$ & References \\
\hline ureC $(\mathrm{F})$ & 5' GAATAAGCTTTTAGGGGTGTTAGGGG '3 & 294 & $\begin{array}{c}\text { Safaei et al. } \\
\quad(2011)\end{array}$ \\
\hline $\operatorname{ureC}(\mathrm{R})$ & 5' GCTTACTTTCTAACACTAACGCGC '3 & & \\
\hline
\end{tabular}




\section{RESULTS}

Table 1: Incidence of isolated Helicobacter species in the examined hen's eggs shell samples.

\begin{tabular}{lccc}
\hline \multicolumn{1}{c}{ Type of samples } & $\begin{array}{c}\text { No. of samples } \\
\text { analyzed }\end{array}$ & $\begin{array}{c}\text { No. of } \\
\text { Positive samples }\end{array}$ & $\%$ \\
\hline Balady hen's egg shells & 30 & 10 & 33.33 \\
\hline Poultry farms hen's egg shells & 30 & 9 & 30 \\
\hline
\end{tabular}

Table 2: Incidence of different isolated Helicobacter species recovered from the examined hen's eggs shell samples.

\begin{tabular}{lcccc} 
& \multirow{2}{*}{ Isolated Helicobacter species } & \multicolumn{3}{c}{ Percentage of positive shell samples } \\
\cline { 2 - 5 } & \multicolumn{2}{c}{ Balady } & \multicolumn{2}{c}{ Farms } \\
\cline { 2 - 5 } H. pylori & No./30 & $\%$ & No./30 & 13.33 \\
\hline H. cinaedi & 5 & 16.67 & 4 & 10 \\
\hline H. felis & 2 & 6.67 & 3 & 6.67 \\
\hline H. pullorum & 2 & 6.67 & 2 & - \\
\hline Total & 1 & 3.33 & - & 30 \\
\hline
\end{tabular}

Table 3: Incidence of isolated Helicobacter species in the examined hen's eggs content samples.

\begin{tabular}{lccc}
\hline \multirow{2}{*}{ Type of samples } & No. of samples analyzed & \multicolumn{2}{c}{ Positive samples } \\
\cline { 3 - 4 } & & 30 & No. \\
\hline Balady hen's egg contents & 30 & - & 3.33 \\
\hline Poultry farms hen's egg contents & 30 & - \\
\hline
\end{tabular}

Table 4: Incidence of different isolated Helicobacter species recovered from the examined hen's eggs content samples.

\begin{tabular}{ccccc}
\hline \multirow{2}{*}{ Isolated Helicobacter species } & \multicolumn{5}{c}{ Positive egg content samples } \\
\cline { 2 - 5 } & \multicolumn{3}{c}{ Balady } & \multicolumn{2}{c}{ Farms } \\
\cline { 2 - 5 } & No./30 & $\%$ & No./30 & \% \\
\hline H. pullorum & 1 & 3.33 & - & - \\
\hline Total & 1 & 3.33 & - & - \\
\hline
\end{tabular}

Table 5: Comparison between the incidence of $H$. pylori in the examined hen's egg shell samples by using biochemical and PCR technique.

\begin{tabular}{lccccc}
\hline \multirow{2}{*}{ Examined samples } & \multicolumn{4}{c}{ Positive samples } \\
\cline { 2 - 5 } & \multicolumn{2}{c}{ biochemical } & \multicolumn{2}{c}{ PCR } \\
\cline { 2 - 5 } Balady hen's egg shells & No/30 & $\%$ & No/30 & \multirow{2}{*}{13.33} \\
\hline Poultry farms hen's egg shells & 5 & 16.67 & 4 & 13.33 \\
\hline Total isolates & 4 & 13.33 & 4 & 26.66 \\
\hline
\end{tabular}


Table 6: Relation between biochemical and PCR technique in isolated H. pylori.

\begin{tabular}{lcccc}
\hline \multirow{2}{*}{ Examined samples } & \multirow{2}{*}{$\begin{array}{c}\text { No. of examined } \boldsymbol{H} . \\
\text { pylori }\end{array}$} & \multicolumn{2}{c}{ Positive samples } \\
\cline { 2 - 4 } & $\mathbf{5}$ & No. & $\%$ \\
\hline Balady hen's egg shells & 4 & 4 & $\mathbf{8 0 \%}$ \\
\hline Poultry farms hen's egg shells & 4 & $100 \%$ \\
\hline \multicolumn{1}{c}{ Total } & 9 & 8 & $\mathbf{8 8 . 8 9 \%}$ \\
\hline
\end{tabular}

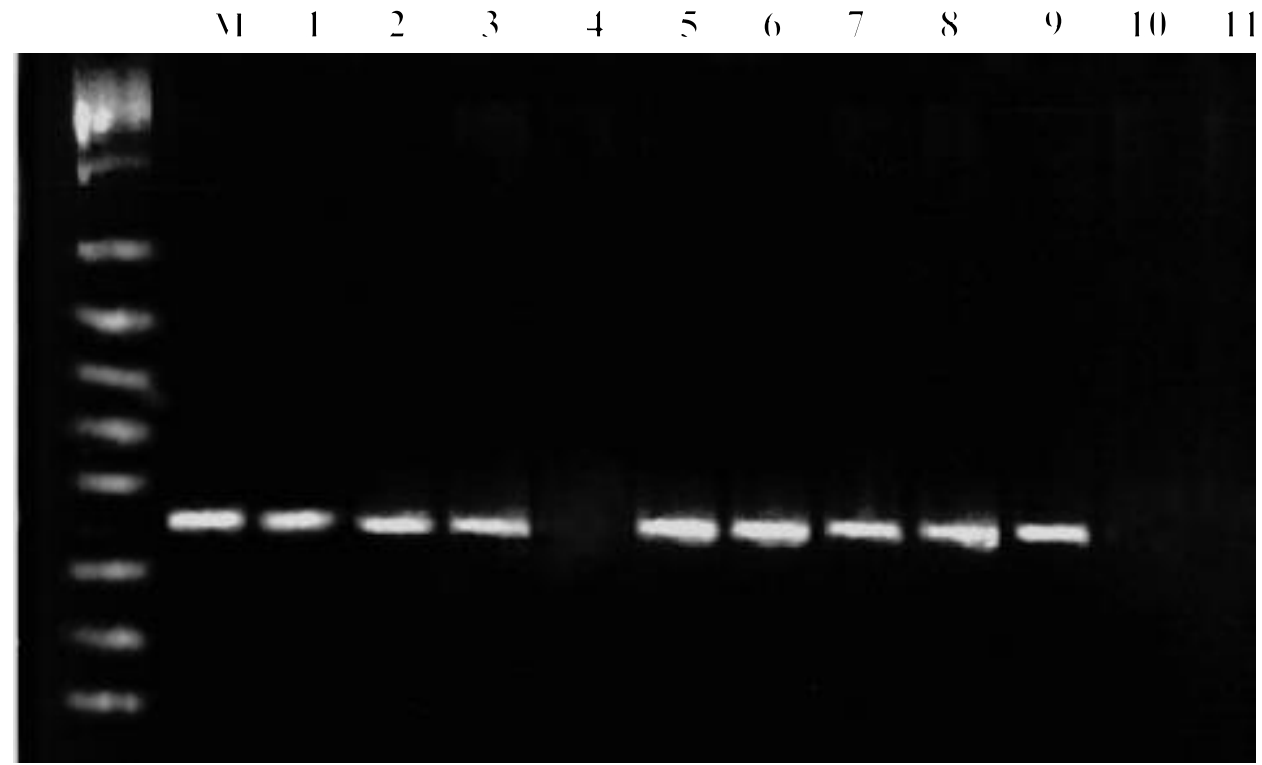

Photograph 1: Agarose gel electrophoresis of PCR amplification products using ureC gene as specific primer for identification of $\mathrm{H}$. pylori.

Lane M: 100 bp ladder as molecular DNA marker.

Lane 1: Control positive H. pylori for ureC gene.

Lane 11: Control negative for $H$. pylori.

Lanes $(\mathbf{2}, \mathbf{3}, \mathbf{4}, \mathbf{6}, \mathbf{7}, \mathbf{8}, 9$ and 10): Positive strains as $H$. pylori.

Lane 5: Negative $H$. pylori isolated from balady egg shell samples.

Lanes (2, 3, 6, and 9): Strains isolated from balady egg shell samples.

Lanes (4, 7, 8 and 10): Isolated strains from poultry farms egg shell samples.

\section{DISCUSSION}

The idea of the present study dealing with the incidence of Helicobacter species in hen's eggs was coming from the fact that the organism was originally isolated from the feces of broilers and laying hens (Burnens et al., 1994, Stanley et al., 1994). In addition, a preliminary study showed its presence on $60 \%$ of poultry carcasses pointing to it as a potentially important food- associated human pathogen.

Therefore, the discovery of Helicobacter species has sparked an interest in exploring the pathogenic potential of these organisms in food especially in eggs because eggs are considered as an essential food element for growth and maintenance of human health in addition to its high nutrient contents, low caloric value and ease of digestibility. However the nutrients that make eggs a high - quality food for human are also a good medium for bacteria (Frazier and Westhoff, 1986).

It was observed from Table 1 that shells contamination with Helicobacter species on (HPSPA) in balady hens eggs was $(33.33 \%)$ and in poultry farms eggs was $(30 \%)$. This confirms the opinion of Burnens et al. (1994) and Stanley et al. (1994) that the contamination may came from feces of hens. The relatively high incidence of Helicobacter species contamination was observed in examined balady hen's eggs shell samples in percentage of $(33.33 \%)$, and in percentage of $(30 \%)$ in the examined egg shell samples from poultry farms hen's eggs. This is could be attributed to the bad hygiene during the production of eggs. Also, eggs are liable to contamination from feces of hens according to (Burnens et al., 1994, Stanley et al., 1994) who stated that the organism was originally isolated from the feces of broilers and 
laying hens. The Helicobacter species are recovered from the examined balady hen's egg content indicating the bad hygienic measures in the farmer's houses.

Data summarized in Table 1 indicated that the contamination of the balady hen's eggs shell samples was slightly higher than the contamination of the poultry farms egg shell samples. Presence of Helicobacter species in both types of egg indicate the bad hygienic measures of the production of hen's eggs. Data showed in Table 1 was less than the result obtained by Abdel Hameed and Sender (2011) indicating the good hygienic measures during production of eggs.

The external shell contamination could be important for the shell life and the food safety of consumption of eggs and egg's products (Smith et al., 2000). This is observed from the obtained results in Table 2 that the identified Helicobacter species from examined balady hen's egg shells samples were $H$. pylori 5 (16.67\%), H.cinaedi 2 (6.67\%), H. felis $2(6.67 \%)$ and $H$. pullorum $1(3.33 \%)$. These results agree with those of Abdel Hameed and Amin (2010) who make the same protocol in isolation and identification of Helicobacter species as described by Stevenson et al. (2000). In the present results in Table 2 of investigated poultry farms hen's egg shells samples the isolated strains were identified as $H$. pylori $4(13.33 \%), H$. cinaedi 3 (10\%) and $\mathrm{H}$. felis $2(6.67 \%)$.

Table 3 showed that 1out of 30 examined fresh content of balady eggs samples were contaminated with Helicobacter species but the study failed to isolate any Helicobacter species from examined fresh contents of poultry farms hen's eggs. This may be due to competition effect or using antibiotics or due to other factors which need further investigation.

In the present study it was clear that incidence of different Helicobacter species in the examined hen's eggs content from both baladi and poultry farms hen's egg was less than the results obtained by Abdel Hameed and Amin (2010). This indicates the hygienic measures applied leading to minimizing egg content contamination.

Regarding to data presented in Table $4 \mathrm{H}$. pullorum was the identified Helicobacter species (3.33\%) recovered from the examined balady hen's egg contents. On the other hand Helicobacter species failed to be detected in examined poultry farms hen's egg contents which agree with the results obtained by both Abdel Hameed and Amin (2010) and Abdel Hameed and Sender (2011). These results may be due to presence of natural inhibitory substances in the egg.

H. pullorum was isolated from the liver, duodenum, and caecum of broiler and layer chickens, and from humans with gastroenteritis. It is a non-gastric urease negative Helicobacter species colonizing the lower bowel, and has been linked with enteritis and hepatitis in broiler chickens and laying hens and diarrhea, gastroenteritis, liver disease in humans. H. pullorum can be considered a food borne human pathogen (Fox et al., 1998).

H. cinaedi has been found in association with enteritis, proctocolitis and asymptomatic rectal infections in humans (Franklin et al., 1996).

Table 6 indicated that conventional method led to identification of 9 bacterial isolates as $H$. pylori 5 from balady hen's egg shells and 4 from poultry farms hen's egg shells. The percentage of $H$. pylori in examined balady egg shell samples by using PCR assay was $4(80 \%)$ from 5 examined samples and was $4(100 \%)$ from 4 examined poultry farms egg shell samples.

In the present study as shown in Table 6 the conventional method led to identification of 9 bacterial isolates as $H$. pylori, based on biochemical tests. 8 from $9(88.88 \%)$ isolates were confirmed as $H$. pylori with PCR by detection of one PCR product on agarose gel that matched the predicted size and confirmed the actual size of $294 \mathrm{bp}$ that corresponded to ureC gene region of the gene.

Electrophoresis analysis of PCR amplification products using genus specific primer (ureC gene) showed that (Photo1). (M) Ladder marker100 bp; lanes $(2,3,4,6,7,8,9,10)$ isolates positive for $H$. pylori where, lane (5) isolates negative for $H$. pylori which isolated from balady egg shell samples, lanes $(2,3,6,9)$ isolated from balady egg shell samples and lanes $(4,7,8,10)$ isolated from poultry farms egg shell samples. PCR amplification with the primer generated an expected size product with a length of $294 \mathrm{bp}$ from 8 H. pylori strains tested (Photo1). The PCR assay employed in this work specifically targets a region of the ureC gene which has been shown to be unique and essential for growth of $H$. pylori. It has been reported that detecting this gene improves sensitivity and specificity of recognition of $H$. pylori in samples containing prokaryotic cells as well as many organic impurities (Safaei et al., 2011).

Results of biochemical identification of Helicobacter species by using conventional method revealed that 9 isolate of samples (15\%) out of 20 samples were identified as $H$. pylori, $5(16.66 \%)$ strains recovered from balady egg shell samples and 4 (13.33\%) strains from poultry farms hen's egg shell samples. By using PCR technique for identification of suspected isolates, the results revealed that 8 out of 20 samples isolated were identified as $H$. pylori, where 4 from balady egg shell samples and 4 from poultry farms hen's egg shells samples. 
So as noticed from the present results, the specificity of PCR technique for identification of $H$. pylori that previously identified by using conventional technique was more accurate. Stanley et al. (1994) and Ceelen et al. (2006) obtained the same specificity of the protocol and its ability to discriminate between closely related species. The results of PCR of the isolated $H$. pylori were nearly similar to the results obtained by Abdel Hameed and Amin (2010) which confirms the specify of PCR methods.

It is known that several factors have been implicated in egg contamination. Among these are feces of the birds, litter material, improper handling of the eggs by retailers, unhygienic conditions of the markets where these eggs are being sold, contaminated egg crates, packing and poor storage methods (Bruce and Drysdale, 1994). Others are cloths and hands of poultry workers, the environment, dust transporting marketing and weather conditions. Eggs in many stores were exposed to high temperature and low humidity which favors the growth of microbes, especially fungi and hence the rapid decrease in the quality of eggs.

\section{CONCLUSION}

The results of this work emphasized that baladi hen's egg shells were contaminated by some Helicobacter species including $H$. pylori, $H$. felis, $H$. pullorum and $H$. cinaedi, and poultry farms hen's egg shells were contaminated by some Helicobacter species including $H$. pylori, $H$. felis and $H$. cinaedi, in different percentages. This reflects bad hygienic measurements of laying hens, which probably constitute the major source of eggs contamination. The incidence of Helicobacter species in balady egg shell samples was higher than that of poultry farms hens eggs shell samples. The incidence of Helicobacter species in egg shell samples was higher than that of egg content samples and that clarify the bad hygienic measurements of laying hens, which probably constitute the major source of eggs contamination. The results of this investigation showed that only one egg content sample from examined balady hen's egg was contaminated with Helicobacter species. The results of this work emphasized that the poultry farms egg content samples were free from any Helicobacter species.

Therefore, the aforementioned data proved that we must pay great attention to the problems of these pathogens in our foods. Consequently, more restriction and preventive measures should be taken to improve the quality of eggs and clean egg production to protect consumers from being infected by Helicobacter which require many precautions.

\section{REFERENCES}

Abdel Hameed, K.G. and Amin, W.F. (2010): Using of PCR assay for identification of Helicobacter species in hen's eggs. Veterinary World, 3:404408.

Abdel Hameed, K.G. and Sender, G. (2011): Prevalence of $H$. pullorum in Egyptian hen's eggs and in vitro susceptibility to different antimicrobial agents. Animal Science Papers and Reports, 29: 257-264.

Board, R.G. and Fuller, R.C. (1994): Microbiology of the Avian Egg. $1^{\text {st }}$ ed., Chapman and Hall,: $94-$ 128.

Boyanova, L. (2011): H. pylori. Caister Academic Press. International Standard book.

Bruce, J. and Drysdale, E.M. (1994): Trans-shell transmission. Microbiology of the avian egg. Chapman and Hall, London. pp.: 63-91.

Burnens, A.; Stanley, J.; Morgenstern, R. and Nicolet, $J$. (1994): Gastroenteritis associated with $H$. pullorum. Lancet, 344: 1569-1570.

Butcher, G.P. (2003): Gastroenterology: An Illustrated Colour Text. Elsevier Health Sciences. p.: 25.

Ceelen, L.; Decostere, A.; On, S.W.L.; Van den Bulck, K.; Baele, M.; Ducatelle, R. and Haesebrouck, F. (2006): H. pullorum in chickens, Belgium. Emerging Infectious Diseases, 12: 263- 267.

Ceelen, L.; Decostere, A.; Verschraegen, G.; Ducatelle, R. and Haesebrouck, F. (2005): Prevalence of $H$. pullorum among patients with gastrointestinal disease and clinically healthy persons. J. Clinical Microbiology, 43:29842986.

Drumm, B.; Prez-Prez, G.I.; Blaser, M.J. and Sherman, P.M. (1990): Intrafamilial clustering of $H$. pylori infection. New England j.of Medicine, 322: 359-363.

Ellen, H.A.; Bottcher, R.W.; Von Wachebfelt, E. and Takai, H. (2000): Dust levels and control methods in poultry houses. J. Agricultural Safety Health, 6: 275-282.

Forman, D.; Webb, P. and Parsonnet, J. (1994): H. pylori and gastric cancer. Lancet, 343:243-244.

Fox, J.G.; Dewhirst, F.E.; Shen, Z.; Feng, Y.; Taylor, N.S.; Paster, B.J.; Ericson, C.N.; Lau, C.N.; Correa, P.; Araa, J.C. and Roa, I. (1998): Hepatic Helicobacter species identified in bile and gall bladder tissue from Chileans with chronic cholecyctitis. Gastroenterology, 114: 775-763.

Franklin, C.L.; Beckwith, C.S.; Livingston, R.S.; Riley, L.K. and Gibson, S.V. (1996): Isolation of a novel Helicobacter species, $H$. cholecystus sp. Non. from the gall bladders of Syrian hamsters with cholangiofibrosiss and centrolobular pancreatitis. J.Clinical Microbiology, 34: 29522958. 
Frazier, W.C. and Westhoff, D.C. (1986): Food Microbiology. TMH Ed, N.Y., pp:540.

Gast, R.K.; Guardo Bouldin, J. and Holt, P.S. (2004): Colonization of reproductive organs and internal contamination of eggs after experimental infection of laying hens with Salmonella Heidelberg and Salmonella enteritidis. Avian Diseases, 48: 863-869.

Goodwin, C.S.; Armstrong, J.A. and Chilvers, T. (1989): Transfer of Campylobacter pylori and Campylobacter mustelae to Helicobacter gen. nov. as H. pylori Comb. nov. and H. mustelae comb. respectively. International j. Systematic and Evolutionary Microbiology, 39:397-405.

Hangombe, B.M.; Sharma, R.N.; Skjerver, E. and Tuchilli, L.M. (1999): Ocurrence of Salmonella enteritidis in pooled table eggs and marketready chicken carcasses in Zambia. Avian Diseases, 43: 597-599.

Kianpour, F.; Mehdipour, S.Z. Mazroee, M.A.; Kazemeini, H.R.; Rahimi, E. and Jafari, A. (2014): Prevalence of $H$. pylori in buffalo milk in Iran. Trends in Life Sci., 3: 28-33.

Komoto, K.; Haruma, K.; Kamada, T.; Tanaka, S.; Yoshihara, M.; Sumii, K.; Kajiyama, G. and Talleg, N.J. (1998): H. pylori infection and gastric neoplasia: correlation with histological gastritis and tumor histology. American $j$. Gastroenterology, 93:1271-1276.

Kusters, J.G.; Van Vliet, A.H. and Kuipers, E.J. (2006): Pathogenesis of $H$. pylori Infection. Clinical Microbiology Rev., 19: 449-490.

Lambert, J.R.; Lin, S.K. and Aranda-Michel, J. (1995): $H$. pylori. Scandinavian $J$. Gastroentrology, 30: 33-46.

Marshall, B.J. and Warren, J.R. (1983): Unidentified curved bacilli on gastric epithelium in active chronic gastritis. Lancet. 321 (8336):1273-5.

Miyamota, T.; Horie, T.; Babo, E.; Sasai, K.; Fukata, T. and Arakawa, A. (1998): Salmonella penetration through eggs shell associated with freshness of laid eggs and refrigeration. $J$. Food Protection, 61: 350-353.

Moats, M.A. (1980): Classification of bacteria from commercial egg washers and washed and unwashed eggs. J. Applied and Environmental Microbiology, 40: 710-714.

On, S.L.W.; Holmes, B. and Sackin, M.J. (1996): A probability matrix for the identification of Campylobacters, Helicobacters and allied taxa. J. Applied Bacteriology, 81:425-432.

On, S.L.W.; Hynest, S. and Wadstrom, T. (2002): Extragastric Helicobacter species. Helicobacter, 7: 63-67.

Osei-Somuah, A.; Otsyina, H.R.; Arthur, C.T.; Nortey, P.W.K and Hammond, V. (2003): Microbial quality of table eggs sold on selected markets in Accra. Ghana Vet. Med. Assoc. Bi- Annual Newslett, 6: 314-318.
Ryan, K. (2010): Sherris Medical Microbiology. McGraw-Hill. pp.:73, 576.

Safaei, H.G.; Rahimi, E.; Zandi, A. and Rashidipour, A. (2011): H. pylori as a zoonotic infection: the detection of $H$. pylori antigens in the milk and faeces of cows. J. Research in Medical Sciences, 16: 184-187.

Shah, D.; Shringi, S.; Besser, T. and Call, D. (2009): Molecular Detection of Food borne Pathogens, Boca Raton: CRC Press, In: Liu, D. (Ed.), Taylor \& Francis Group, Florida, USA, pp.: 369-389.

Smith, A.; Rose, S.P.; Wells, R.G. and Pirgozliev, V. (2000): The effect of changing the excreta moisture of caged laying hen on the excreta and the microbial contamination of their shells. British Poultry Science, 41: 168-173.

Solnick, J.V. and Vandamme, P. (2001): H. pylori: Physiology and Genetics. Mobley HLT, Mendz GL, Hazell SL, (Eds.), Washington (DC): ASM Press, Ch. 5, Taxonomy of the Helicobacter Genus.

Solnick, J.V.; Hansen, L.M.; Canfield, D.R. and Parsonnet, J. (2001): Determination of the Infectious Dose of Helicobacter pylori during Primary and Secondary Infection in Rhesus Monkeys (Macaca mulatta). J. Infection and Immunity, 69:6887-6892.

Speck, M.L. (1976): Compendium of Methods for Microbiological Examination of Food. ed., American Public Health Association, Washington, D.C.

Stadelman, W.J. and Cotterill, O.J. (2001): Egg Science and Technology. $4^{\text {th }}$ ed., Avi Publ. Co., Westport, CT.

Stanley, J.; Linton, D.; Burnens, A.P.; Dewhirst, F.E.; On, S.L.; Porter, A.; Owen, R.J. and Costas, M. (1994): H. pullorum sp. nov. genotype and phenotype of a new species isolated from poultry and from human patients with gastroenteritis. Microbiology, 140: 3441-3449.

Stevenson, T.H.; Bauer, N.; Lucia, L.M. and Acuff, G.R. (2000): Attempts to isolate Helicobacter from cattle and survival of $H$. pylori in Beef products. J. Food Protection, 63:174-178.

Sykora J.; Pazdiora, P.; Varvarovska, J.; Pomahacová, R.; Stozický F. and Siala, K. (2006): Current epidemiological and clinical issues regarding Helicobacter pylori infection in childhood. Epidemiol Mikrobiol Imunol, 55: 3-16.

Vale, F.F. and Vitor, J.M. (2010): Transmission pathway of Helicobacter pylori: Does food play a role in rural and urban areas? International j. Food Microbiology, 138: 1-12.

Whincup, P.H.; Mendall, M.A.; Perry, I.J.; Strachan, D.P. and Walker, M. (1996): Prospective relations between $H$. pylori infection, coronary heart disease, and stroke in middle aged men. Heart, 75: 568-572. 
World Health Organization: The Globocan project, (2010): [http://www.irac.fr/en/media-center/ iarcnews/index 1 . php year $=2010]$

Young, V.B.; Chien, C.C.; Knox, K.A.; Taylor, N.S.; Schauer, D.B. and Fox, J.G. (2000):
Cytolethal distending toxin in avian and human isolates of $H$. pullorum. J. Infectious Diseases, 182: 620-623.

\section{تواجد أنواع الهيلكوباكتر مع أولوية خاصة للهيلكوباكتر بيلوري فى بيض الدجاج مروة عزت عبل الجيل خليف ، مصطفى خليل مصطفى ، نجاح محمد سعد ، مروة محد نبيل حسن}

E-mail: Ahmednofel122@yahoo.com Assiut University web-site: www.aun.edu.eg

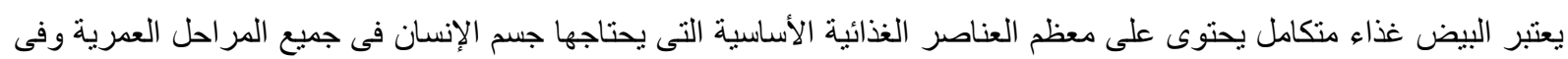

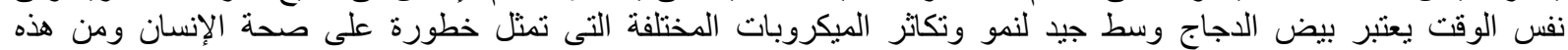

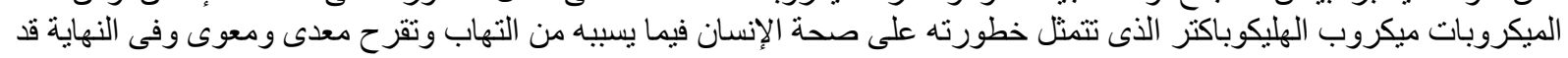

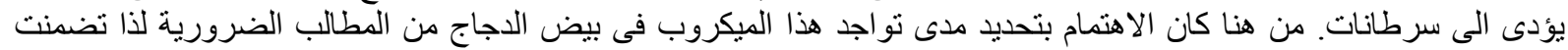

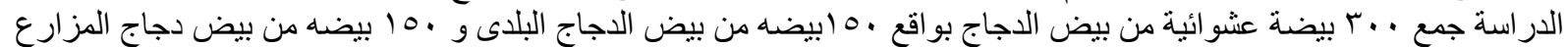

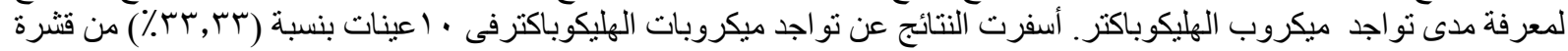

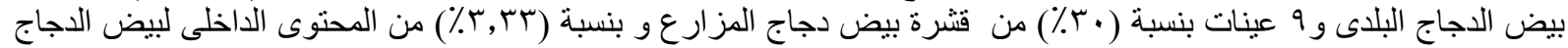

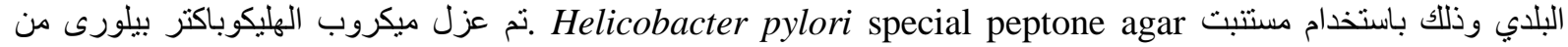

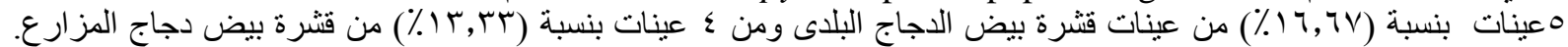

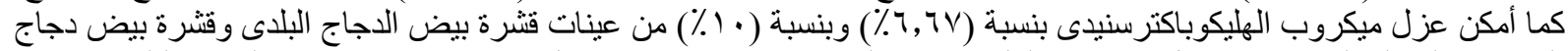

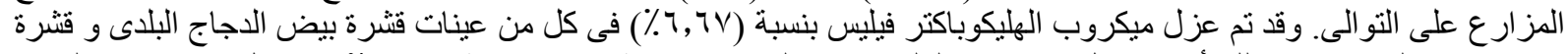

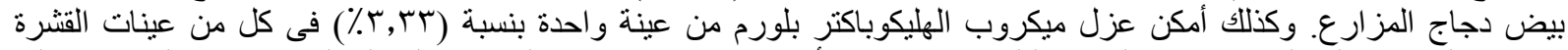

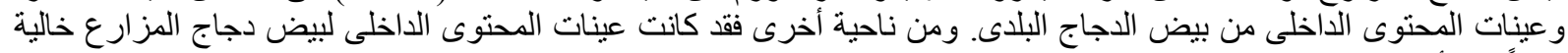

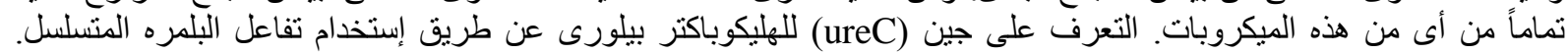

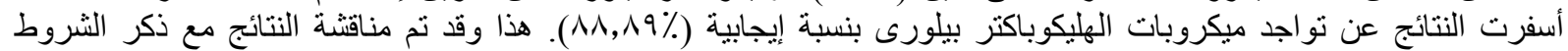

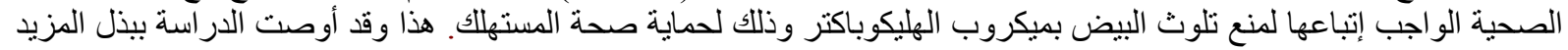

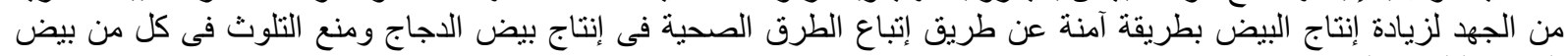

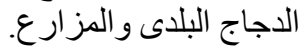

